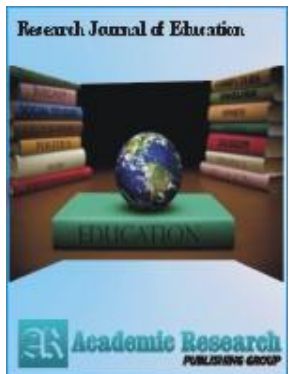

Research Journal of Education

ISSN: 2413-0540

Vol. 1, No. 2, pp: 15-20, 2015

URL: $\underline{\text { http://arpgweb.com/?ic=journal\&journal=15\&info=aims }}$

\title{
A Model of Educational Character in High School Al-Istiqamah Simpang Empat, West Pasaman, West Sumatera
}

\author{
Muhammad Kristiawan
}

Islamic Management of Education Study Program State Islamic Studies of Batusangkar, West Sumatera, Indonesia

Abstract: This research was aimed at describing how is the model of educational character in High School Al-Istiqamah Simpang Empat, West Pasaman, West Sumatera and what strategy that was used by High School Al-Istiqamah to keep the quality outputs which have character, then this research became a model in organizing educational character related to the sustainable development and capacity human building. To get the aim of the research, the researcher used qualitative ethnography methodology. This study carried out on the condition of natural and cultural nature, it is more descriptive, it emphasis on the process rather than the product or outcome, data analysis conducted inductively, and further emphasize the significance (data behind the observed). The techniques of collecting data consisted of interviewing, observation, documentation, and triangulation. The model of educational character was (1) religious; (2) moderate; (3) smart; and (4) independent. The Strategy which was done to keep the output was forming the school's culture such behavior, tradition, daily life, and symbols which were applied by all members of school and society around school.

Keywords: Model; Educational Character; High School.

\section{Introduction}

Indonesia has a variety of complex problem, which is not finished. For the political aspect the problem includes confusion and constitutional system of government, ineffective state institutions, which do not support the party system, and the development of political pragmatism (Suprapto, 2014). Then the economy, the issue includes economic paradigm is not consistent, dualistic economic structure, fiscal policy has not been independent, banking and financial system that is not impartial, and trade and industrial policies are liberal. Then the socio-cultural aspects, the current problem is waning sense and national ties, disorientation religious values, the waning of social cohesion and integration, and a weaker positive mentality (Central Leader of Muhammadiyah, 2009).

Indonesia needs a great quantity and quality of human resources as the main supporter of the development (Ikhsan, 2014). Large population is the most important for the progress and setbacks of a nation depends on human factors. The problems of politic, economic, social can also be completed by human resources. However, to solve the problems and deal with the high civilization competition become more advanced, Indonesia needs revitalization and strengthening strong character of human resources. One aspect that can be done to prepare for the strong human character is through education (Suprapto, 2014). Education is the only key that can achieve strong human resources (Suyatno, 2010).

Indonesia's needs now related to the importance of capacity building for sustainable development. Capacity building has been embedded in the objectives and programs of work of many international organizations and they offer a wide range of capacity building activities (United Nations Environment Program (UNEP); Division of Technology Industry and Economics (DTIE); and Economics and Trade Branch (ETB), 2006).

Capacity building as a means to promoting sustainable development is broad and can encompass a multitude of activities. In its publication "Capacity Building for Sustainable Development" UNEP described capacity building as building abilities, relationships and values that will enable organizations, groups and individuals to improve their performance and achieve their development objectives. Capacity building was also described as initiating and sustaining a process of individual and organizational change that can equally refer to change within a state, civil society or the private sector, as well as a change in processes that enhance cooperation between different groups of society. This definition puts emphasis on three aspects: (a) capacity building as the catalyst and constant fuel for a process of change, (b) the importance of building institutional capacity, and the (c) involvement of a wide range of different groups in society (United Nations Environment Program (UNEP); Division of Technology Industry and Economics (DTIE); and Economics and Trade Branch (ETB), 2006).

It must be said that building the requisite human capita for the attainment of sustainable development by all countries requires both a new ideology of life and innovative approach to education. In this regard, sustainable 
development should become a regular part of the programs and curricula of our educational system at all levels. As noted by Peters "education is an instrument for training human resources to optimize productivity by encouraging technical progress and by promoting cultural conditions conducive to social and economic change" (Peters, 2013).

One of the missions of Indonesia that realize its vision of future has been included in the Outline of State Policy (GBHN) which embody the national education system and the democratic climate in order to strengthen noble character, creative, innovative, insightful nationality, intelligent, healthy, disciplined and responsible, skilled and master of science and technology in order to develop human qualities of Indonesia (Depdiknas, 2003). It is clearly visible on Guidelines mandated policy where education improves the academic and professional skills and to improve welfare education so that teachers are optimally functioned, especially in the improvement of education and moral character in order to restore the prestige of the institution and staff; empower educational institutions both school and outside the school as the center of civilizing values, attitudes, and skills, and to increase the participation of families and communities that are supported by adequate infrastructure.

Education is a planned effort to mentor and learning for the individual to develop and grow into a human being with an independent, responsible, creative, knowledgeable, healthy, and noble good views of the physical and spiritual aspects (Lickona, 1992). Human morality, which has a very high morality required to set up or constructed. The Indonesian people are not just emit a glow of the importance of education, but rather how the Indonesian nation capable of realizing the concept of education by way of coaching, training and human resource development in a sustainable and equitable Indonesia. This is in line with the Law. 20 of 2003 on National Education System as saying that the purpose of education is "... to be a man who is faithful and devoted to God Almighty, noble, healthy, knowledgeable, skilled, creative, independent, and become citizens of a democratic and accountable".

Based on the function and purpose of national education, it is clear that education at all levels should be organized systematically. This is related to the formation of the character of the students so that they can compete, has an ethics, and has morals, manners in interacting with the public. Based on research at Harvard University in the United States (Djalil and Megawangi, 2006), it turns out a person's success is not determined solely by the knowledge and technical skills (hard skills), but rather by the ability to manage themselves and others (soft skills). This research suggests that success is determined only approximately $20 \%$ of the hard skills and the remaining $80 \%$ by the soft skills. Even the most successful people in the world to be successful due to the more widely supported the ability of soft skills rather than hard skills. This suggests that educational character is essential for learners improved. Seeing people of Indonesia itself is also very weak in mastering soft skills.

Seeing the present and future, the availability of human resources is characterized by a vital necessity. This was done to prepare for the global challenges and competitiveness of the nation. It is not easy to generate human resources contained in the Act. The problem is Indonesia still do not reflect the human ideals of education are expected. For example, today cases, there are still many students who cheat on exams when on, being lazy, conflict between fellow students, doing promiscuity, drugs, and others. On the other hand, found teachers who always give bad examples to students. For example, teachers rarely make fraud in the certification and the national exam (UN). This condition is frankly very sad and worrying for Indonesia which has been independent since 1945. Indeed, this problem cannot be generalized, but at least it is a fact that should not be ignored because we do not want the children of our nation would become an immoral man, as now we often see on television that displays news as theft, robbery, rape, corruption, and kidnapping, carried out not only by adults but also by children teens.

Departing from the above problems and theories, need a formal attempt to set conditions, facilities, activities, education, and a curriculum that leads to the formation of character and manners of the young generation to have a strong legal foundation. However, the signal is only realized when the moral crisis that hit all levels of society. No exception is also in children of school age. To prevent more severe moral crisis, now those efforts initiated through educational character nation. In granting the national educational character in schools, too many experts are disagreeing each other. There are at least three opinions are evolving. First, given that the national educational character as a stand-alone subject.The second opinion, given the national educational character integrated in Civics subject, religious education, and other relevant subjects. The third opinion, national educational character is integrated into all subjects.

From the three opinions above, this study tends to think that all three national educational characters are integrated into all subjects. Because the role of the educational character in building human capital through high quality educational that promotes creativity, innovation and adoption of modern technology for the successful implementation of sustainable development cannot be overemphasized.A primary issue that will be revealed in this study is the acquisition of an overview of educational character at High School Al-Istiqamah.

This study is conducted at High School Al-Istiqamah, Simpang Empat, West Pasaman, West Sumatera, Indonesia. High School Al-Istiqamah is one private school in West Pasaman established in 1989. This school is a strategically located place in the district Simpang Empat. When viewed from the development from year to year the progress quite well. High School Al-Istiqamah has been conducting instruction with PAIKEM (Effective, Active, Innovative, Creative, and Fun Learning); develop work ethics and excellence all school stakeholders; cultivate discipline in carrying out the duties and responsibility; improve learning achievement through additional learning activities and guidance; increase the quality of teachers and students by using media and information technology, training and seminars; fostering mental and personality of students through religious and moral education; implementing a program of self-development in accordance with the talents of students, improving students' received in a Favorite Higher Education; manage education with quality standards, and educate the graduates 
embody intelligent, emotional and intellectual. All the things that have been done by High School Al-Istiqamah leads to the educational character.

Observing the importance of educational character, this study attempts to provide some ideas for strengthening the quality of human character that is capable of forming a strong and resilient private. This study will refer to the role of education, especially education as the key to successful implementation of educational character in high school and Al-Istiqamah both family and society.

This study has two research focuses which needs the answer, how is a model of educational character in AlIstiqamah and the strategies undertaken to maintain the quality graduates of character. Then, this study aims to describe the model of educational character and describe what strategy to maintain the quality of graduates that character.

\section{Procedure}

This study was qualitative ethnography methodology. This study (1) carried out on the natural condition. Researcher directly to the data source management of model educational character at high school Al-Istiqamah and the researcher is the key instrument; (2) it is more descriptive, the data collected on the management of a model educational character at the school are words or images, so it does not emphasize on the number; and (3) a greater emphasis on the process rather than the product or outcome; (4) data analysis conducted inductively; and (5) further emphasize the data behind the observed (Sugiyono, 2007).

In this study, the researcher used observation to collect data from multiple data sources in the form of an event, place or location and objects as well as the recorded image (Sutopo, 2002). In this study the researcher used direct observation technique by attending the event. The observation used to know the characteristics and management strategies of educational character at high school Al-Istiqamah.

Interviews were conducted by communicating directly with those who can support the data obtained relating to the problems studied in order to obtain the data either oral or written. Interview technique used in this study was indepth Interviewing because investigator felt "did not know what the unknown". Thus, interviews were conducted with the questions "open-ended", and led to the depth of information (Sutopo, 2002) of the primary data. Researcher conducted interviews with questions to obtain information related to the models and management strategies of characteristic of Education at high school Al-Istiqamah.

Third, the study documents as additional data, but these data serve to clarify and supplement the primary data. It was conducted by the research documents relating to the management models and strategies of educational character at high school Al-Istiqamah.

Fourth, the triangulation of data collection techniques is combining various techniques of data collection and data sources that already exist. When the researcher collects data by using triangulation means the researcher tests the credibility of the data. Testing was done by checking the credibility of the data with a variety of data collection techniques and data sources (Sugiyono, 2007). In this case, researcher combined the results of interviews with documents and looking for a discrepancy between the results of interviews with the document.

\section{Findings}

Model of educational character at high school Al-Istiqamah were (1) religious, it has attitude and personality pious, honest, trustworthy, generous, helping each other, and tolerant; (2) moderate, it has a life that is not radical attitude and personality is reflected in the balance between individual and social, material and spiritual oriented and able to live in diversity and cooperation; (3) intelligent, it has attitude and personality of a rational life, love science, open-minded forward; and (4) independent, it has an independent attitude and personality, discipline, thrift, respect for time, hard working, entrepreneurial, and have a love of high nationality without losing orientation universal human values and relationships among civilizations of nation-nation.

High School Al-Istiqamah is not only form a personal smart and nice, but also mold them into good actors to change his own life, which will donate the change in the social order becomes more justice, kind, and humane. The high school teachers are involved in the process of learning, discussion, and take the initiative in an effort to build educational character. Then they are also responsible for a model that has moral values and take advantage of the opportunity to influence students. This means that high school educators at Al-Istiqamah ought to be "uswah hasanah" living for each learner. They should also be open and ready to discuss with the students about the various good values. Teachers are also required to provide an understanding of the character of the growth of students through collaboration and participation in decision making. Then the teachers reflect on moral issues such as routine questions to ensure that the students experience character development. In addition, they also explain or clarify to students on a continuous basis about the value of the good and the bad.

Other things were done by high school teachers Al-Istiqamah in the implementation of educational character were (1) applying participatory methods that involve active learning of students; (2) creating a conducive learning environment; (3) providing explicit educational character, systematic, and continuous, involving aspects knowing the good, loving the good, and the good acting; and (4) pay attention to the uniqueness of each students in the use of learning methods.

Without an exception, all high school teachers Al-Istiqamah make their selves as an authoritative figure model for the students. Therefore, it will not have meaning if the teacher teaches Civics solve a problem as opposed to the 
way of democracy, while another teacher authoritarian way, or a teacher of religious education in answering questions from the students by giving the example of the Prophet and friends, while another teacher just said carelessly in answering.

In making Lesson Plan the teachers must include instructional impact and impact drover. Impact accompaniment is educational character should be developed, cannot be reached directly, it can only be reached after several learning activities take place. In the assessment of learning outcomes, all teachers should measure students' abilities in all aspects. By using that judgment it can be imaged the figure of actual student. It means in determining students' success must be judged from various areas such as cognitive, affective and psychomotor. The student actually assessed the ability of reasoning on the problems of Mathematics. It is also assessed the ability of educational character by doing honesty not cheating, and ask friends and this is addressed because the acts are not good. In addition, they are also assessed the ability of their movements to work on the problems with writing a regular exam, neat, and easy to read.

High School Al-Istiqamah implements educational character through a holistic approach, which integrates character development into every aspect of school life such (1) developing relationships between students, teachers, and community; (2) caring community of learners where there is a clear bond that links students, teachers, and school; (3) social emotional learning and academic learning equivalent; (4) cooperation and collaboration among students become more mainstream over the competition; (5) values such as fairness, respect, and honesty become a part of everyday learning both inside and outside the classroom; (6) students are given many opportunities to practice moral behavior through activities such as learning to provide services; (7) discipline and classroom management focus on solving problems than rewards and punishments; and (8) model of teacher-centered learning should be abandoned and turn to democracy classroom where teachers and students come together to build a unified, norms, and solve problems.

Meanwhile, the role of High School Al-Istiqamah in implementing educational character include (1) collecting teachers, parents and students together to identify and define the elements of character that they want to emphasize; (2) provide training for teachers on how to integrate educational character into the life and culture of the school; (3) form a partnership with parents and the community so that students can hear the behavior of the characters is important for success in school and in life; and (4) provide an opportunity for the principal, teachers, parents and the community to be a model of social and moral behavior.

Strategies were undertaken by High School Al-Istiqamah in maintaining the quality of graduates is shaping school's culture, the attitudes, traditions, daily habits, and symbols are practiced by all the schools, and the community around the school. The culture which is applied such (1) practice religion followed by the stages of adolescent development; (2) understand the advantages and disadvantages of self; (3) demonstrate a confident attitude; (4) abide the social rules that apply in the wider environment; (5) appreciate the diversity of religions, cultures, ethnicities, races, and socioeconomic groups in the national scope; (6) find and apply information from the surrounding environment and other sources logically, critically, and creatively; (7) demonstrate ability to think logically, critically, creatively and innovatively; (8) demonstrate ability to learn independently according to its potential; (9) demonstrate ability to analyze and solve problems in everyday life; (10) describe the natural and social phenomenon; (11) utilize environmentally responsible manner; (12) apply the values of togetherness in the life of society, nation, and state in order to create unity within the unitary state of the Republic of Indonesia; (13) appreciate the art and the national culture; (14) appreciate the work tasks and have the ability to work; (15) apply a clean, healthy, fit, safe, and enjoy free time well; (16) communicate and interact effectively and respectfully; (17) understand the rights and responsibilities of self and others in relationships in the community, value dissent; (18) read and write a short script; (19) demonstrate listening, speaking, reading, and writing skills in Indonesia and English; (20) master the knowledge necessary to follow secondary education; and (21) have an entrepreneurial spirit.

\section{Discussions}

It is reasonable if high school educational character at Al-Istiqamah integrated into all subjects. The reasons for that are because it increases the noble character of the students is the responsibility of all teachers. All teachers should become the authoritative figure model for the students. Implementation of integrated educational character into all subjects, it is more adequate development in an integrated curriculum model and integrated learning by determining the center core on the subjects that will be learned.

The model of educational character at High School Al-Istiqamah supports a paper presented by Suyatno (Rector of Muhammadiyah University Prof. DR. HAMKA) in the National Workshop "Development of Culture and Educational character Nation" by Kopertis Region 3 Jakarta, January 12, 2010. The paper reported that the formation of a strong human character is needed to deal with global challenges more severe. Human character is formed through a process of formal, non-formal, and informal. To synergism, the role of educators in educational character is vital that students become a religious man, modest, intelligent, and independent in accordance with the ideals and goals of national education and the character of Indonesia.

The findings support the research which was done by Enemark (2003). This paper argued that even if the key focus may be on education and training to meet short and medium term needs, capacity building measures should be addressed in the wider context of developing institutional infrastructures for implementing land policies in a sustainable way. Capacity building measures must be addressed at three levels: the societal level (policies, legal frameworks and accountability), the organizational level (institutional infrastructures and organizational 
effectiveness), and individual level (technical and professional competencies and responsibilities). Capacity building should be seen as a comprehensive methodology aiming to provide a sustainable outcome through assessing and addressing a whole range of relevant issues and their interrelationships.

The findings also support UNESCO that commits the Organization to providing targeted assistance to the LDCs in all of its spheres of competence. Targeted action for the LDCs during the 2010-2011 program cycle focuses on (1) promoting quality education for all, particularly through capacity development, so as to prepare young people for the world of work and to promote economic growth, foster civic participation, personal development and empower women; (2) providing policy advice and capacity building in Science, Technology and Innovation for sustainable development and poverty reduction; (3) promoting the sustainable management of freshwater, ocean and terrestrial resources, including renewable sources of energy, as well as disaster preparedness and mitigation; (4) promoting mitigation and adaptation to climate change, notably through enhanced education and public awareness; (5) promoting culture as a powerful engine for economic growth to generate income and stimulate employment; (6) developing free, pluralistic and independent media, training journalists and media professionals and fostering ICT applications for enhancing quality; and (7) Impact of teaching and learning processes.

Educational character, it is absolutely necessary not only at school, but also at home and in the social environment. Nowadays the participant in educational character is not only for early childhood to adolescence, but also adulthood. Absolutely it is necessary for the survival of this nation. Imagine what kind of competition that emerged in the year 2021? It is clear that it will become our burden and parents today. At that time, the children of today will face competition from his colleagues from around the country in the World. While we are still going to work in that year, we will feel the same feelings. The demands of human resources in 2021 would require good character.

However, the character is the key to individual success. From a study in the United States, 90\% of cases are caused by the dismissal of bad behavior as irresponsible, dishonest, and poor interpersonal relationships. In addition, there are other studies that indicate that $80 \%$ of a person's success in society is determined by the emotional quotient.

For Indonesia today, educational character also means making earnest efforts, systematic and sustainable way to awaken and strengthen the awareness and reassurance that all Indonesian people will not have a better future without building character people of Indonesia. In other words, there is no a better future can be achieved without honesty, without increasing self-discipline, without persistence, without the spirit of high learning, without developing a sense of responsibility, without fostering unity amidst diversity, without the spirit of contributing to the progress, and without a sense of confidence and optimism.

\section{Conclusions}

Based on the results obtained in this study, the model of educational character at High School Al-Istiqamah and strategies were undertaken to maintain quality of the graduates are characterized as follow:

a. Model of educational character at high school Al-Istiqamah were (1) religious, it has attitude and personality pious, honest, trustworthy, generous, helping each other, and tolerant; (2) moderate, it has a life that is not radical attitude and personality is reflected in the balance between individual and social, material and spiritual oriented and able to live in diversity and cooperation; (3) intelligent, it has attitude and personality of a rational life, love science, open-minded forward; and (4) independent, it has an independent attitude and personality, discipline, thrift, respect for time, hard working, entrepreneurial, and have a love of high nationality without losing orientation universal human values and relationships among civilizations of nation-nation.

b. Strategies were undertaken by High School Al-Istiqamah in maintaining the quality of graduates is shaping school's culture, the attitudes, traditions, daily habits, and symbols are practiced by all the schools, and the community around the school. The culture which is applied such (1) practice religion followed by the stages of adolescent development; (2) understand the advantages and disadvantages of self; (3) demonstrate a confident attitude; (4) abide the social rules that apply in the wider environment; (5) appreciate the diversity of religions, cultures, ethnicities, races, and socioeconomic groups in the national scope; (6) find and apply information from the surrounding environment and other sources logically, critically, and creatively; (7) demonstrate ability to think logically, critically, creatively and innovatively; (8) demonstrate ability to learn independently according to its potential; (9) demonstrate ability to analyze and solve problems in everyday life; (10) describe the natural and social phenomenon; (11) utilize environmentally responsible manner; (12) apply the values of togetherness in the life of society, nation, and state in order to create unity within the unitary state of the Republic of Indonesia; (13) appreciate the art and the national culture; (14) appreciate the work tasks and have the ability to work; (15) apply a clean, healthy, fit, safe, and enjoy free time well; (16) communicate and interact effectively and respectfully; (17) understand the rights and responsibilities of self and others in relationships in the community, value dissent; (18) read and write a short script; (19) demonstrate listening, speaking, reading, and writing skills in Indonesia and English; (20) master the knowledge necessary to follow secondary education; and (21) have an entrepreneurial spirit. 


\section{References}

Central Leader of Muhammadiyah (2009). Revitalization on vision and national character. PP Muhammadiyah: Yogyakarta.

Depdiknas (2003). The law 20 of 2003 on national education system. www.depdiknas.go.id

Djalil, S. A. and Megawangi, R. (2006). Upgrading the educational quality at Aceh through the model of educational holistic based character. Scientific Oration on Dies Natalis 45 Syiah Kuala University Banda Aceh:

Enemark, S. (2003). Capacity Building for Developing Sustainable Land Administration Infrastructures. Paper presented at WPLA/FIG Workshop Athens, 28-31 May 2003. Spatial Information Management for Sustainable Real Estate Markets and Best Practice Guidelines on Nation-wide Land Administration:

Ikhsan, A. (2014). Construct mental revolution on education. Jambi: Jambiekspres. http://www.jambiekspres.co.id/berita-19248-mengkonstruksi-revolusi-mental-dalam-pendidikan.html

Lickona, T. (1992). Educating for character: How our schools can teach respect and responsibility. Bantam Books: New York.

Peters, A. A. (2013). Building human capital for sustainable development: Role of The University. A paper delivered on the occasion of the 2013 University of Ibadan Registry Discourse:

Sugiyono (2007). Qualitative Research Method.: CV. Alfabeta: Bandung.

Suprapto (2014). Mental revolution from education. Unika Darma Cendikia: Surabaya.: http://www.jawapos.com/baca/artikel/6669/revolusi-mental-dimulai-dari-pendidikan

Sutopo, H. B. (2002). Qualitative Research Method.: UNS Press: Surakarta.

Suyatno (2010). Developing cultural education and national character. Article presented on National Forum by Kopertis 3 Jakarta:

United Nations Environment Program (UNEP); Division of Technology Industry and Economics (DTIE); and Economics and Trade Branch (ETB) (2006).'Ways to increase the effectiveness of capacity building for sustainable development'.Paper presented at the Concurrent Session 18.1 The Marrakech Action Plan and Follow-up, 2006 IAIA Annual Conference. Stavanger, Norway. 